\title{
HIERARCHICAL HABITAT SELECTION AND REPRODUCTIVE SUCCESS OF THE RINGED WARBLING-FINCH IN CHACO WOODLANDS
}

\author{
Rocío Sánchez ${ }^{1,3}$, Pedro G. Blendinger ${ }^{1,2}$, Eugenia Moyano Wagner ${ }^{1}$, And Eduardo Martín ${ }^{1}$ \\ ${ }^{1}$ Instituto de Ecología Regional, Universidad Nacional de Tucumán, CC 34, 4107 Yerba Buena, Tucumán, Argentina \\ ${ }^{2}$ Consejo Nacional de Investigaciones Científicas y Técnicas (CONICET), Argentina
}

\begin{abstract}
Breeding birds must choose habitat at a multiple scales, from landscapes to nest sites. It is important to understand how birds make these decisions and the relationships between these choices and breeding success. Over 3 years, we studied nest-site selection of the Ringed Warbling-Finch (Poospiza torquata) in the semiarid Chaco of Argentina at the scales of the landscape, nest patch, and nest site. At the landscape scale, Ringed WarblingFinches established nesting territories in shrub-grassland exclusively. Within shrub-grassland, nest patches and nest sites selected differed in few attributes of vegetation cover from patches and sites that were available, and those differences varied from year to year. Only in the year when brood survival and breeding success were lowest did features of sites of successful and depredated nests differ clearly. The Ringed Warbling-Finch selects features of nesting habitat at the landscape, nest-patch, and nest-site scales. Implications of choices at the scales of nest patch and nest site appear to vary by year, but the presence of shrubs, particularly Geoffroea decorticans and Ziziphus mistol, was most frequently important. The species appears to be plastic in its selection of nest patches and nest sites, perhaps because these choices do not lead to consistent selective advantages.
\end{abstract}

Key words: $\quad$ breeding biology, spatial scale, breeding success, Poospiza torquata, habitat selection.

Selección Jerárquica de Hábitat y Éxito Reproductivo de Poospiza torquata en el Bosque Chaqueño

Resumen. Las aves reproductoras deben seleccionar el hábitat a múltiples escalas, desde los paisajes hasta los sitios de nidificación. Es importante entender cómo las aves toman estas decisiones y las relaciones entre estas selecciones y el éxito reproductivo. Durante 3 años, estudiamos la selección del sitio de nidificación de Poospiza torquata en el Chaco semiárido de Argentina a las escalas de paisaje, parche de nidificación y sitio de nidificación. A la escala de paisaje, $P$. torquata estableció los territorios de nidificación exclusivamente en arbustales-pastizales. Dentro de los arbustales-pastizales, los parches de nidificación y los sitios de nidificación seleccionados difirieron en pocos atributos de la vegetación de los parches y sitios que estaban disponibles, y estas diferencias variaron de año en año. Solo en el año en que la supervivencia de la nidada y el éxito reproductivo fueron los más bajos, las características entre los sitios con nidos exitosos y con nidos depredados variaron claramente. P. torquata selecciona las características del hábitat a las escalas de paisaje, parche de nidificación y sitio de nidificación. Las implicancias de las selecciones a las escalas de parche de nidificación y sitio de nidificación parecen variar por año, pero la presencia de arbustos, particularmente de Geoffroea decorticans y Ziziphus mistol, fueron características claves en la selección. La especie parece ser plástica en su selección del parche de nidificación y en su sitio de nidificación, tal vez debido a que estas selecciones no conducen a ventajas selecticas consistentes.

\section{INTRODUCTION}

In locating their nests within the available habitat, many birds use space preferentially in response to physical, ecological, and behavioral factors (Ramsay et al. 1999, Davis 2005, Goodenough et al. 2009). Differences between sites selected for nesting and other available sites have been associated with the physiognomy of the habitat, chiefly vegetation structure and composition. The selection of certain characteristics of the vegetation is related to a microclimate adequate for development of embryos and nestlings (Hobbs et al. 2006, Robertson 2009), protection of the brood from unfavorable environmental factors (Hartman and Oring 2003, Gjerdrum et al. 2005), and to avoiding predation (Mezquida and Marone 2002, Nalwanga et al. 2004). Many factors, however, can influence nest-site selection and rate of nest predation, and patterns consistent across species are few (Boulton et al. 2003). The history of each individual (Martin 1995), its past experiences (Nevoux et al. 2008), the site where it bred previously (Hallworth et al. 2008), intraand interspecific interactions with birds that share the habitat (Andrén 1991, Hingrat et al. 2008), the risk of nest predation (Boulton et al. 2003), all are factors that bear on nest-site

Manuscript 14 December 2011; accepted 6 September 2013.

${ }^{3}$ Corresponding author. E-mail: rociospp@gmail.com

The Condor, Vol. 115, Number 4, pages 893-901. ISSN 0010-5422, electronic ISSN 1938-5129. (C) 2013 by The Cooper Ornithological Society. All rights reserved. Please direct all requests for permission to photocopy or reproduce article content through the University of California Press's Rights and Permissions website, http://www.ucpressjournals.com/ reprintInfo.asp. DOI: 10.1525/cond.2013.110206 
selection. Especially among birds nesting in the open, nest predation is the main source of variation among individuals in reproductive success (Whittingham et al. 2002, Neto 2006). Through natural selection, loss of nests will lead to behavioral adjustments to reduce those losses. Thus the features in which sites of successful and failed nests differ might reflect natural selection favoring the use of habitats where failure is reduced (Martin 1998, Chase 2002).

Addressing habitat selection at different spatial scales allows to capture more information and to explain the variation in use of space, as a process sensitive to the scale of analysis (Luck 2002, Chalfoun and Martin 2007, Mayor et al. 2009). Because nesting birds cannot track accurately and simultaneously the habitat characteristics on several spatial scales, bird decisions could follow a hierarchical structure reflecting their habitat perception and specific requirements (Kristan 2006). For example, selection of habitat types occupied during the breeding season occurs at the landscape scale, the establishment of breeding territories involves selection of a patch of habitat, and the specific site where the nest is built is selected on a micro site scale (Bergin 1992, Luck 2002).

In this study we evaluate selection of nesting sites by the Ringed Warbling-Finch (Poospiza torquata) at multiple spatial scales and examine the association of physical properties of the chosen sites with breeding success. The rate of failure of nests of the Ringed Warbling-Finch is high because of predation (Mezquida and Marone 2003), making this species attractive for an investigation of potential adaptive advantages of nest-site selection, over which predation must exert a strong selection pressure (Martin 1998). Specifically, we ask the following questions: (1) At the landscape scale, does the Ringed Warbling-Finch prefer a particular habitat for nesting, in relation to those available in the semiarid Chaco? (2) Does it select patches and nest sites with distinctive features within the habitats where it establishes breeding territories? (3) Is there a relationship between reproductive success and vegetative features of nest sites? To answer these questions we evaluated variables of vegetation structure and composition potentially relevant to establishing the territory and building the nest at three spatial scales and over three breeding seasons. We evaluated both multi-year and annual nest-site selection by Ringed Warbling-Finch. If attributes of the nesting site influence the breeding success, thus suggesting potential adaptive advantages, the immediate neighborhood of successful nests should have distinctive features with respect to failed nests.

\section{METHODS}

\section{STUDY SPECIES}

The Ringed Warbling-Finch occurs in semiarid environments in the foothills of the Andes and lowlands of South America, from central Bolivia and western Paraguay south to central
Argentina (Ridgely and Tudor 1994). In Argentina the Ringed Warbling-Finch inhabits open forests, grasslands, and shrubby steppes of the north and center of the country, reaching the southern limit of its range in the province of Río Negro. Mezquida and Marone (2003) described aspects of its reproductive biology in the central portion of the Monte desert, Mendoza province, Argentina. The breeding season begins in the middle of the austral Spring (late October) and ends by midsummer (February). The following data are from Mezquida and Marone (2003): the nest is an open cup $5.2 \pm 0.1$ (mean $\pm \mathrm{SE}$ ) $\mathrm{cm}$ in height and $6.1 \pm 0.1 \mathrm{~cm}$ in external diameter made of vegetable fibers and thick hairs. On average, the period from initiation of nest building to laying of the first egg is 6-9 days, whereas incubation and parental care extend for $11.1 \pm 0.3$ and $9.5 \pm 0.2$ days, respectively. The average clutch consists of 3.2 eggs, which are incubated exclusively by the female. Nestlings are fed by both parents. During the breeding season males perch in sites with intermediate exposure in the foliage. During spring and summer Ringed Warbling-Finches feed mostly on insects, to a lesser extent on seeds gathered mainly in the standing vegetation; the birds rarely forage on the ground (Blendinger 2005, Sagario 2010).

\section{STUDY AREA}

Our study took place at the Estación Experimental Agropecuaria La María $\left(28^{\circ} 03^{\prime} \mathrm{S}, 64^{\circ} 15^{\prime} \mathrm{W}\right)$, a field station belonging to the Instituto Nacional de Tecnología Agropecuaria in Santiago del Estero province, Argentina. The climate is subtropical-semiarid with a mean annual temperature of $20^{\circ} \mathrm{C}$, and a mean annual rainfall of $627 \mathrm{~mm}$, concentrated in spring and summer (data from 1989 to 2007). The station encompasses 6750 ha and includes several types of vegetation of the semiarid Chaco region, including forest, shrub-grassland, and pure grassland (Codesido and Bilenca 2004, Biani et al. 2005). The upper stratum of the forest is over $8 \mathrm{~m}$ high, and the discontinuous canopy is dominated by Aspidosperma quebracho-blanco (Apocynaceae) and Schinopsis lorentzii (Anacardiaceae). A second lower stratum of trees of 4 to $8 \mathrm{~m}$ height consists of younger trees of A. quebracho-blanco and S. lorentzii as well as Prosopis spp. (Fabaceae) and Ziziphus mistol (Rhamnaceae). A third herbaceous stratum is poorly developed; the ground is largely bare. Pure grasslands are dominated by Elionurus muticus (Poaceae) and to a lesser extent by Cenchrus pilcomayensis, Schizachyrium tenerum, and Pappophorum pappipherum (Poaceae), in addition to the broadleafed herbs Rhynchosia senna and Indigofera parodiana (Fabaceae; Brassiolo et al. 1993, Kunst et al. 2007). Major shrubs of shrub-grasslands are several species of the genus Acacia (Fabaceae), Cercidium australis (Fabaceae), Geoffroea decorticans (Fabaceae), Capparis atamisquea (Capparidaceae), Celtis pallida (Ulmaceae), and Jodina rhombifolia (Santalaceae). This habitat has a dense herbaceous layer of composition similar to that of pure grasslands. 
We established our study site in 120 ha where the vegetation is regulated by man-made fires and extensive livestock farming, which create a mosaic of pure grasslands and shrub-grassland with isolated trees and patches of forest. In a preliminary survey (breeding season 2007) we traversed the station searching for sites with adult Ringed Warbling-Finches and signs of nesting activity so we could select sites for further study. We chose this area of the station because it was a continuous patch of habitat large enough to accommodate many breeding pairs.

\section{SELECTION OF HABITAT, NEST PATCH, AND NEST SITE}

Our intensive study extended over three breeding seasons, from October to January 2008-09, 2009-10, and 2010-11 (hereafter seasons 2008, 2009, and 2010, respectively). During the preliminary survey in 2007 (see above) we found the birds much more concentrated in shrub-grasslands that in other habitats, and this pattern continued through the remainder of the study. To measure the habitat in territories at the landscape scale, we defined 20 points in each of the three main habitats in the study area (forest, shrub-grassland, and pure grassland) during the peak of the egg laying (November) of 2010. We distributed the 60 points randomly, at least $150 \mathrm{~m}$ apart; at each point count we recorded all adult Ringed Warbling-Finches seen or heard in a $50 \mathrm{~m}$ radius during $10 \mathrm{~min}$. We recorded the abundance of adults and their activities, such as singing or carrying nesting material or food in the bill, as well as presence of active or old nests.

To characterize the vegetation of nest patches and nest sites, we designed a sampling protocol based on Martin et al. (1997). Because we found no active nests in the forest or pure grassland, we quantified the vegetation in the shrub-grassland only. To characterize patches available for nesting of the Ringed Warbling-Finch in the shrub-grasslands, we defined circular plots $60 \mathrm{~m}$ in diameter $(0.28 \mathrm{ha})$ and separated by $200 \mathrm{~m}$ to cover the entire area in which we searched for nests (Fig. 1). The central point of each plot (the "available patch") was set in a shrub of attributes similar to those in which Ringed WarblingFinches nest. We defined a similar plot centered at each nest (the "nest patch"). We selected a diameter of $60 \mathrm{~m}$ so as to include the area within which, on the basis of our preliminary survey, a territorial male spends most of its time. Moreover, breeding birds move more than $60 \mathrm{~m}$ from the nest, so this distance was not so large that nest patches overlapped available patches.

Each 60-m plot consisted of four subplots ( $10 \mathrm{~m}$ in diameter) in which one subplot was located at the center of the larger plot (shrub or nest) and the remaining three were located at $120^{\circ}$ from each other around the center with one subplot due north of the center. The centers of outer subplots were $30 \mathrm{~m}$ from the central subplot (Fig. 1). In each subplot we evaluated (1) vegetation cover, visually estimating

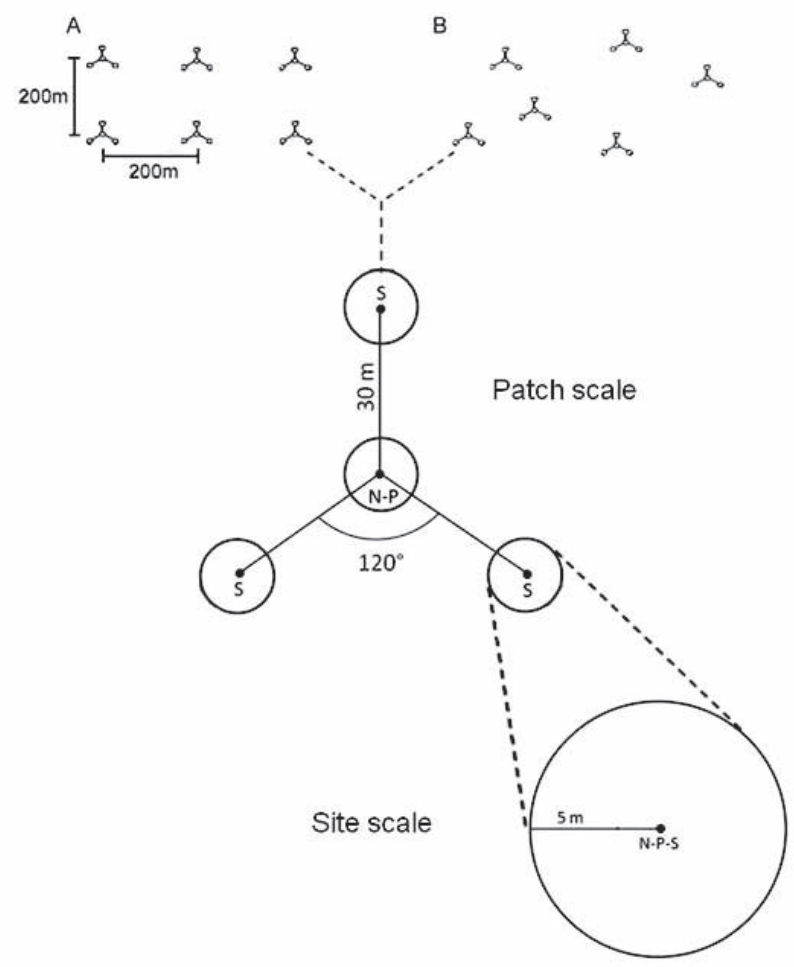

FIGURE 1. Design of measurements of attributes of vegetation around points available for nests of the Ringed Warbling-Finch (A) and actual nests (B). At the scale of the patch, we sampled the central subplot and three satellite subplots (S) separated from each other at a $120^{\circ}$ angle and located $30 \mathrm{~m}$ from the central subplot. At the scale of the site we, sampled only the central subplot. Each subplot includes the area delimited by a $5-\mathrm{m}$ radius around a randomly selected point $(\mathrm{P})$ or nest $(\mathrm{N})$.

the percentage ( $5 \%$ intervals) of bare soil, the herbaceous stratum including forbs, grasses and shrubs $<1 \mathrm{~m}$ in height, and the stratum of shrubs 1-4 m in height, (2) number of shrubs of the species in which the Ringed Warbling-Finch nests most frequently (i.e., Geoffroea decorticans, Ziziphus mistol, Acacia aroma, Castela coccinea and Prosopis sp.), and (3) total number of shrubs 1-4 m tall and rooted within the subplot, regardless of the species. We recorded the latter variable because breeding pairs concentrate their activities (perching, feeding, nesting) in the shrubby stratum. Finally, for each variable we averaged the values of all four subplots in order to obtain a single mean estimate per plot. We measured all vegetation variables in each of the three breeding seasons, except for shrub abundance at the patch scale in 2008. At the smaller scale of the nest site, we considered only the subplots of $10 \mathrm{~m}$ diameter $(0.008 \mathrm{ha})$ centered on a focal nest or shrub as described above; these we called "nest sites" and "available sites," respectively (Fig. 1). At this scale we contrasted the same variables of cover, composition, and shrub density described for "nest patches" and "available patches." 


\section{NEST-SITE SELECTION AND NEST SUCCESS}

We compared vegetation-cover variables and species composition at sites of successful nests with those of nests that were depredated. For the shrub supporting the nest, we measured its crown diameter and total height. For the nest, we considered its height, (distance from the upper edge of the nest to the ground) and the distance between the nest and the shrub's central stem as an indication of the support's firmness. In shrubs without central stem (i.e., A. aroma) we measured the branch with the thickest diameter, and to estimate the distance to the shrub's axis we projected a line from the center of the shrub to the nest. We related attributes of the nest's site to measures of its success (number of successful nests per pair and breeding season).

\section{NEST SEARCH AND MONITORING}

Over the three breeding seasons, we searched the entire shrub-grassland for nests intensively along contiguous linear transects $2 \mathrm{~m}$ wide, to avoid any bias favoring detection of conspicuous nests. Every shrub in these transects was inspected. This intensive search was complemented with direct observations of singing males and adults carrying nest material or food in the bill. We recorded the coordinates of each nest by the Global Positioning System, date found, and presence and number of eggs or nestlings. We monitored each nest every $2-5$ days (mean $3.2 \pm 1.0$ days) until the pair ceased its activities. We increased the frequency of visits to nests toward hatching and through the nestling phase. For nests that failed during incubation, we estimated the degree of embryonic development if we knew the date the eggs were laid. We estimated nestlings' age by on patterns of growth described in detail by Mezquida and Marone (2003). We considered a nest successful when one or more nestlings fledged and depredated when we found empty a nest known to have had eggs or nestlings. We did not record any nest that suffered partial predation.

\section{STATISTICAL ANALYSES}

We used nonparametric tests in all analyses of vegetation composition and cover variables because of non-normal frequency distributions, high kurtosis, and asymmetry, even after applying ordinary data transformations, $x^{1 / 2}$ and $\ln (x+1)$ for structure and composition, respectively. We report mean $\pm \mathrm{SE}$ (standard error) in all cases and set $\alpha=0.05$ in all tests.

We compared mean values of vegetation cover and composition by breeding seasons at the scales of the nest patch /available patch (0.28 ha) and nest site/available site (0.008 ha) with Kruskal-Wallis or Mann-Whitney tests, depending on the number of breeding seasons compared (two or three). At the scales of both the patch and nest site we used logistic regression to search for vegetation variables, measured at used and available patches and nest sites, that might explain the probability of nesting in a given patch or site. We included attributes of the site as independent variables in the model as follows. In the case of highly correlated variables ( $r>0.6, P<0.001$ ) we kept in the model only the significant variable with the lowest $P$-value. We analyzed each independent variable individually then added variables with $P<0.25$ to build the final model via stepwise selection. The threshold of $\alpha$ for including a variable was 0.05 , for excluding it was 0.1 . We categorized all measured patches and sites on the basis of the agreement between observed and predicted values estimated by the model and set the probability for classifying $Y$ as predicting that a patch or site was used at $>0.5$. We used the Hosmer-Lemeshow test to evaluate the model's fit to the data.

During each breeding season, we compared mean values of vegetation cover and composition at sites with successful nests to those at sites with depredated nests. We used a logistic regression to examine whether nest-site selection was able to explain reproductive success. The dependent variable was nest success, and the independent factors were vegetation structure and composition at the nest-site scale, attributes of the nest support, and location of the nest. We estimated apparent nest success or failure (number of failed nests or successful nests divided by total number of nests) and, considering the high rate of loss of nests to predation, we calculated the daily survival rate by the method of Mayfield (1975) and the variances by following Johnson (1979).

\section{RESULTS}

We found a total of 152 nests with eggs or nestlings during the three years of the study: 65 in 2008, 55 in 2009, and 32 in 2010. The numbers of successful nests were 14, 13, and 4 nests in 2008, 2009, and 2010, respectively. Among 11 species of shrubs and small trees, G. decorticans and Z. mistol were those most frequently used for nesting. The annual frequency of use of other species such as A. aroma and Prosopis sp. was more variable; the former was important for nesting only in 2008, the latter only in 2010 (Fig. 2). Mean values by breeding season of all vegetation variables at the scales of patch and site are available in online Appendix 1, together with the values of Mann-Whitney $U$ tests of the significance of the difference in each variable between nests and random "available" points by year.

\section{SELECTION OF HABITAT, NEST PATCH, AND NEST SITE}

Habitat selection. At the landscape scale, Ringed WarblingFinches clearly select shrub-grasslands for nesting (KruskalWallis, $\left.H_{2}=15.53, P<0.001\right)$. We observed adults at $45 \%$ of the 20 points located in the shrub-grassland: at two of them we found a pair with a nest, and at the other seven we found a male singing territorially; we record no adults in the pure grassland or inside the forest.

Nest-patch selection. None of the vegetation attributes we evaluated differed by year in the available patches, except the abundance of Prosopis sp. shrubs $(U=197, P=0.003)$, which 


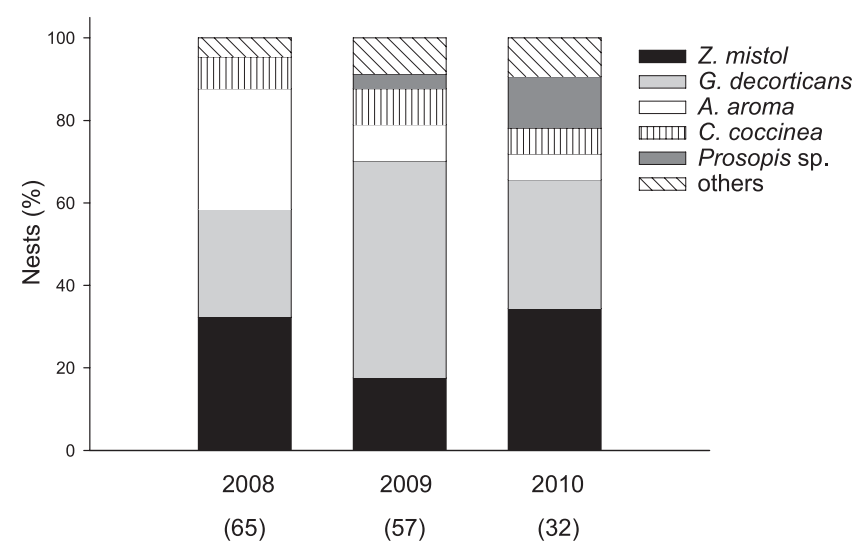

FIGURE 2. Percentage of species of shrubs in which Ringed Warbling-Finches nested over three breeding seasons, 2008-2011. The total number of nests found each year is shown in parentheses.

differed in the two seasons (2009 and 2010) we measured it. However, nest patches differed by year in their mean cover of bare soil and shrubs $\left(H_{2}=10.4, P=0.006 ; H_{2}=22, P<0.001\right.$, respectively) (Fig. 3). Also, mean abundances of Prosopis sp. and total shrubs were greater in 2010 than in $2009(U=497$, $P<0.001 ; U=657.5, P=0.05$, respectively).

In 2008 , the patches with and without nests did not differ in any of the variables measured. In 2009, the patches with and without nests differed only in the abundance of $G$. decorticans $(U=405, P=0.003)$; patches with more shrubs of $G$. decorticans were more likely to have nests (Table 1). Logistic regression correctly classified $69.6 \%$ of samples with a good fit of the model $\left(\chi_{8}^{2}=2.64, P=0.45\right)$. In 2010, the mean cover of shrubs was significantly greater in nest patches than in available patches $(U=275, P=0.004$; Table 1$)$. The logistic regression correctly classified $65 \%$ of the samples with a good fit of the model $\left(\chi_{8}^{2}=9.8, P=0.28\right)$.

When we pooled the three breeding seasons, the nest and available patches differed in none of the vegetation-cover variables. But $G$. decorticans was more abundant in nest patches $(U=1801.5, P=0.01)$; logistic regression showed that greater abundance of this shrub increases the chances of a patch of being used for nesting (Table 1). Sixty-two percent of the samples were correctly classified, with a good fit of the model $\left(\chi_{3}^{2}=2.27, P=0.52\right)$.

Nest-site selection. Available sites did not differ by year in vegetation cover and composition. Sites chosen for nesting significantly differed by year in average cover of bare soil $\left(H_{2}=10.01, P=0.007\right)$, herbaceous vegetation $\left(H_{2}=6.81, P=\right.$ $0.03)$, and shrubs $\left(H_{2}=12.58, P=0.002\right)$ (Fig. 3). Mean abundance of Prosopis per nest site in 2009 differed from that in $2010(U=652.5, P=0.02)$, the two breeding seasons in which we measured it.

In 2008, nest sites did not differ from available sites in vegetation cover, but their abundance of $Z$. mistol, $G$. decorticans, and $A$. aroma was greater $(U=918, P=0.02$;
$U=960.5, P=0.02 ; U=1190.5, P=0.01$, respectively). In 2009 , nest and available sites differed only in the abundance of $G$. decorticans $(U=420, P=0.002)$; sites with more shrubs of $G$. decorticans were more likely to have nests. Logistic regression correctly classified $70 \%$ of the samples with a good fit of the model $\left(\chi_{2}^{2}=1.45, P=0.48\right)$. In 2010 , the shrub cover was greater at the nest sites than at the available sites $(U=340.5, P=0.048)$, and the logistic regression showed the chance of a site having a nest increased with shrub cover. The model correctly classified $61.3 \%$ of samples (model fit: $\chi_{2}^{2}=7.1, P=0.31$; Table 1).

With the three years pooled, nest sites differed from available sites only in the abundance of total shrubs, of $G$. decorticans, and of Z. mistol $(U=50003.5, P<0.001 ; U=$ 5433.5, $P<0.001$; and $U=5842.0, P=0.02$, respectively). These three vegetation attributes explained the greater probability of a site's being used for nesting in a logistic model, which correctly classified $62.6 \%$ of sites with a good fit $\left(\chi^{2}{ }_{5}=\right.$ 10.22, $P=0.07)$.

\section{NEST-SITE SELECTION AND NEST SUCCESS}

We calculated the fate of 143 of the 152 broods found from 2008 to 2010. Nest success was similar in 2008 and 2009 but declined in 2010 (Table 2).

In 2008, successful nests were placed in sites with less shrubby cover than around depredated nests $(U=177, P=$ $0.05)$. The logistic regression correctly classified $73.6 \%$ of the sites with a good fit of the model $\left(\chi^{2}{ }_{7}=9.14, P=0.24\right)$. In 2009 , no variable was correlated with nest fate. In 2010, successful nests differed strongly from failed nests in nest-site vegetation (herbaceous cover: $U=12, P<0.05$; shrub cover: $U=9$, $P<0.05$; Z. mistol abundance: $U=11, P<0.05$; total shrub abundance: $U=6, P<0.01)$, in height $(U=10, P<0.05)$ and crown diameter $(U=8, P<0.05)$ of the nest shrub, and in the nest's distance to the shrubs' stem $(U=4.5, P<0.01)$. In this year, simple logistic regressions specified that most of these variables considered individually explained the probability of a nest's success being greater (Table 3). When all of these variables were included in the final model via stepwise selection, only the distance between the nest and the shrub's stem was related positively with nest success. A logistic regression correctly classified $85 \%$ of samples with a good fit of the model $\left(\chi_{6}^{2}=9.14, P=0.24\right.$; Table 3$)$.

The three breeding seasons pooled, successful and failed nests differed in none of the vegetation variables, but the distance to the shrub's stem tended to be greater for successful nests $(U=924, P=0.02)$. Simple logistic regressions showed that nests located in taller shrubs, in shrubs with wider crowns, and farther from the shrub's stem had a greater probability of success (Table 3). The shrub's height was the only variable retained in the final logistic model, and it was positively related to a nest's probability of success $(77 \%$ of correctly classified nests; model fit: $\left.\chi_{8}^{2}=9.7, P=0.30\right)$. A shrub's height was positively correlated with the diameter of 

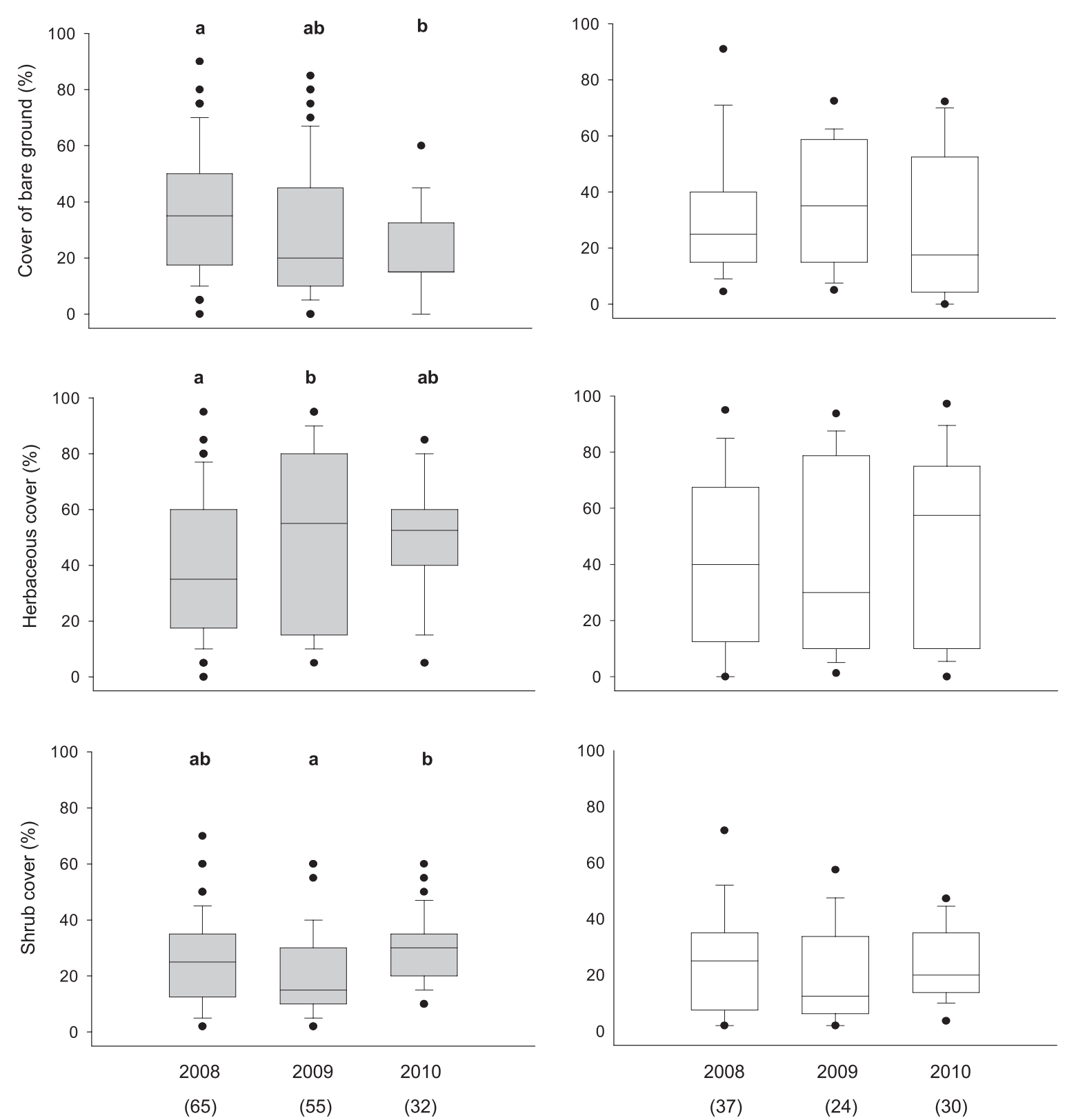

FIGURE 3. Box plots showing distributions (median, quartiles, 95\%, and outliers) of nest sites (left) and available sites (right) with respect to percentage cover of of bare soil, herbaceous vegetation, and shrubs, recorded in over three breeding seasons, 2008, 2009 and 2010. Sample size for each year in parentheses. Letters on top of boxes indicate Bonferroni corrected $(P<0.017)$ significant differences.

its crown $(r=0.79, P<0.001)$ and with the distance of the nest to the shrub's central stem $(r=0.73, P<0.001)$.

\section{DISCUSSION}

In the semiarid Chaco, the Ringed Warbling-Finch selected habitat attributes for nesting at several spatial scales. At the landscape scale, it clearly preferred a combination of shrubland and grassland. Abundances of certain shrubs but no measure of vegetation coverage increased the chances of the birds' nesting in a patch or site. In particular, the presence of the shrub $G$. decorticans was an important vegetation cue for the Ringed Warbling-Finch's breeding at the scales of both the patch and the nest. However, selection criteria at the both of these scales varied from year to year. A nest's success was affected by its location within the shrub but not by characteristics of the surrounding vegetation. The differences between sites with successful and those with depredated nests also varied from year to year. 
TABLE 1. Logistic-regression models with the variables that explained probability of nesting of the Ringed Warbling-Finch being greater within a patch $(0.28 \mathrm{ha})$ or site $(0.008 \mathrm{ha})$.

\begin{tabular}{|c|c|c|c|c|c|}
\hline Scale and variable & Year & $\beta$ & $\mathrm{SE}$ & Wald & $P$ \\
\hline \multicolumn{6}{|l|}{ Nest patch } \\
\hline Geoffroea decorticans & 2009 & 0.42 & 0.20 & 4.21 & 0.04 \\
\hline Shrub cover $(\%)$ & 2010 & 0.07 & 0.03 & 6.36 & 0.01 \\
\hline Geoffroea decorticans & 2008-2010 & 0.17 & 0.08 & 4.93 & 0.03 \\
\hline \multicolumn{6}{|l|}{ Nest site } \\
\hline Geoffroea decorticans & 2009 & 1.13 & 0.54 & 4.44 & 0.04 \\
\hline Shrub cover $(\%)$ & 2010 & 0.04 & 0.02 & 3.95 & 0.05 \\
\hline Geoffroea decorticans ${ }^{\mathrm{a}}$ & 2008-2011 & 0.40 & 0.13 & 9.98 & 0.00 \\
\hline Ziziphus mistol $^{\mathrm{a}}$ & 2008-2011 & 0.56 & 0.17 & 10.10 & 0.00 \\
\hline
\end{tabular}

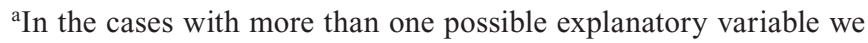
used stepwise selection to select a single variable.

\section{SELECTION OF HABITAT, PATCH, AND NEST SITE}

The shrub-grassland in which the Ringed Warbling-Finch nests in the semiarid Chaco is similar in vegetation physiognomy to that in which it nests in the Monte desert (Marone 1991, Blendinger 2000, Sagario 2010). This habitat is well covered with good herbaceous vegetation and shrubs and has isolated trees or is close to woodland edges. Although variation in the abundance of the Ringed Warbling-Finch has not been interpreted previously in terms of selection of nesting habitat, in the central Monte desert Marone (1991) found its abundance associated with variation in the physiognomy of the vegetation. In that area, nesting Ringed Warbling-Finches are more abundant in open woodlands of Prosopis flexuosa than in shrublands of Larrea cuneifolia. Similarly, in the most arid valleys of the northern Monte desert, the finch prefers nesting in habitat with isolated trees (Prosopis spp.), and its density there is higher than in the shrubby matrix (Blendinger 2000; PGB, pers. obs.).

The Ringed Warbling-Finch clearly selects particular species of plants on which to nest. In both the semiarid Chaco (this study) and in the central Monte desert (Mezquida and Marone 2003) it strongly prefers $G$. decorticans as a nest support in spite of these locations being $1000 \mathrm{~km}$ apart and in different ecoregions. Mezquida and Marone (2003) also found a pattern of nonrandom location of nests with respect to plant species used for nesting in the central Monte desert, where Atriplex lampa (absent from our study area) was one of the species most frequently used as nest support. In the semiarid Chaco, we found the shrub A. aroma used as the support of one-third of the nests in 2008 but of only $7 \%$ in the two subsequent breeding seasons, when it was replaced chiefly by $G$. decorticans and Z. mistol. These changes in the plant supporting the nest were not associated with a different rate of nest success or failure.

In contrast to most published studies of nest-site selection (e.g., Jones and Robertson 2001, Liebezeit and George 2002), that of the Ringed Warbling-Finch varied strikingly from year to year. Such variation could be a response to fluctuations in the physical and biotic environment that expose birds to different pressures in different breeding seasons. In some species selection criteria may change through the breeding season to cope with effects that vary through time, such as insolation (van Riper et al. 1993) and inundation (Gjerdrum et al. 2005), or in space, such as predation risk (Peluc et al. 2008). Although in the same area Ringed Warbling-Finches selected different attributes in different years, we found no changes that might explain this variation in the selection of vegetation structure and composition of nest patches and sites, since changes in the selection criteria were not reflected in variation in attributes of available patches and sites.

\section{NEST-SITE SELECTION AND NEST SUCCESS}

In spite of the high rate of predation on eggs and nestlings, we found few attributes of a nest's location that were associated with its success. Moreover, nest success over the 3 years of the study combined was not affected by vegetation attributes of the nest site. Lack of evidence for selection of attributes favoring breeding success has been reported in many studies of songbirds, and only a small percentage of the features postulated explain a greater probability of success (Mezquida 2004, Davis 2005, Gjerdrum et al. 2005). It has been suggested that high predation. The high pressure of predation on nests may not allow this cause of failure to be associated with

TABLE 2. Percentages and numbers (in parentheses) of successful, depredated, and abandoned nests of the Ringed Warbling-Finch, 2008-2011. For depredated nests we show the daily survival rate and its standard error (SE), calculated after Mayfield (1975) and Johnson (1979), respectively.

\begin{tabular}{|c|c|c|c|c|c|}
\hline \multirow[b]{2}{*}{ Year } & \multirow[b]{2}{*}{ Successful } & \multicolumn{3}{|c|}{ Depredated nests } & \multirow[b]{2}{*}{ Abandoned } \\
\hline & & Depredated & $\begin{array}{c}\text { Daily } \\
\text { survival rate }^{\mathrm{a}}\end{array}$ & $\mathrm{SE}^{\mathrm{b}}$ & \\
\hline $2008(63)$ & $22.2(14)$ & $62.5(39)$ & 0.26 & 0.01 & $15.9(10)$ \\
\hline $2009(53)$ & $24.5(13)$ & $58.5(31)$ & 0.29 & 0.01 & $17.0(9)$ \\
\hline $2010(27)$ & $14.8(4)$ & $66.7(18)$ & 0.17 & 0.01 & $18.5(5)$ \\
\hline 2008-2011 (143) & $21.7(31)$ & $61.5(88)$ & 0.31 & 0.006 & $16.8(24)$ \\
\hline
\end{tabular}


TABLE 3. Variables that individually explained the probability of success of Ringed Warbling-Finch nests being greater in logisticregression models.

\begin{tabular}{|c|c|c|c|c|c|}
\hline Variable & Year & $\beta$ & SE & Wald & $P$ \\
\hline Shrub cover $(\%)$ & 2008 & -0.05 & 0.02 & 3.81 & 0.05 \\
\hline Shrub cover $(\%)$ & 2010 & 0.10 & 0.05 & 3.44 & 0.06 \\
\hline Ziziphus mistol & 2010 & 1.36 & 0.61 & 4.92 & 0.03 \\
\hline Nest shrub height & 2010 & 2.85 & 1.68 & 2.88 & 0.09 \\
\hline Nest shrub diameter & 2010 & 1.14 & 0.68 & 2.79 & 0.09 \\
\hline Nest distance from stem & 2010 & 0.05 & 0.02 & 4.63 & 0.03 \\
\hline Nest distance from stem ${ }^{a}$ & 2010 & 0.05 & 0.02 & 4.63 & 0.03 \\
\hline Nest shrub height & 2008-2011 & 0.73 & 0.37 & 4.03 & 0.04 \\
\hline Nest shrub diameter & 2008-2011 & 0.07 & 0.04 & 2.78 & 0.10 \\
\hline Nest distance from stem & 2008-2011 & 0.02 & 0.01 & 4.89 & 0.03 \\
\hline Nest shrub height ${ }^{\mathrm{a}}$ & 2008-2011 & 1.05 & 0.49 & 4.61 & 0.03 \\
\hline
\end{tabular}

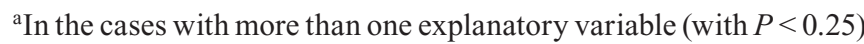
we used stepwise selection, with $\alpha$ for entering set to 0.05 , to select the final model.

attributes of vegetation at the nest site (Filliater et al. 1994, Mezquida and Marone 2002). Chase (2002) suggested that the spatial variation in the relationship between habitat and nest success should favor a more flexible selection of nest sites.

In the Ringed Warbling-Finch, we found a pronounced association between attributes of a nest's location and its success only in 2010, when breeding success was lowest. Because so many clutches were lost during that breeding season, only four of 27 nests were successful. Although definitive conclusions cannot be drawn from so small a sample, the setting of successful and depredated nests differed distinctly. Successful nests were at sites with greater density and cover of shrubs than were depredated nests, and successful nests tended to be placed closer to the periphery of the shrub's crown and higher than depredated nests. Study of annual variability in reproductive success in relation to attributes of the nest site attributes might reveal which attributes are adaptive. In order for a select attribute to confer an adaptive advantage, conditions that increase fitness should recur regularly during an individual's lifespan. Long-term studies following marked individuals, however, are required for the adaptive value of attributes selected for a nest site to be determined with certainty (Martin 1998, Clark and Shutler 1999).

\section{CONCLUSION}

Birds may choose their nesting habitat at multiple spatial scales, selecting it in response to the various pressures that threaten the success of a nest (Marzluff 1988, Wiebe and Martin 1998, Boulton et al. 2003, Chalfoun and Martin 2007). In the semiarid Chaco, the Ringed Warbling-Finch selects certain attributes of vegetation at the scales of the landscape, nest patch, and nest site. Heterogeneous patches of shrubby vegetation and ample herbaceous cover favor establishment of territories. Within these patches, shrubs such as G. decorticans and Z. mistol are essential, as structures to support nests. The plasticity with which the Ringed Warbling-Finch selects nest patches and sites is reflected in annual differences in attributes of the nest patch and site, but in our study we could not identify the adaptive functions of the selection criteria. In general, studies that have evaluated the predictive power of nest-site selection have not succeeded in associating this selection with a clear adaptive advantage (e.g., Misenhelter and Rotenberry 2000, Davis 2005). Evidence of advantages of traits of a nest site that might enhance fitness in critical years emphasizes the importance of studies with spatial or temporal replication, in which nests are exposed to different intensities of selection pressure, especially in predation rate (Peluc et al. 2008, Harrison et al. 2011). Such evidence would allow detection of attributes of the environment that are key under certain scenarios but neutral or even maladaptive under others.

\section{ACKNOWLEDGMENTS}

We thank Instituto Nacional de Tecnología Agropecuaria for allowing us to carry out this study at Estación Experimental Agropecuaria La María, as well as the station's staff, particularly Lucho Ibáñez, Ramón López, Rómulo Ruiz, Ing. Fumagalli, and José Salvatierra for logistic support. We thank Basko and numerous students that collaborated in the field and Fany, Chingo, Gabi, and Gabriela for their help in Árraga. The Instituto de Ecología Regional of the Universidad Nacional de Tucumán provided office space; we thank the contribution and discussions of the Laboratorio de Ecología de Aves of this institute. This study is part of the doctoral dissertation of RS done with financial support from the Consejo Nacional de Investigaciones Científicas y Técnicas, Argentina, and the Unión de Naciones Sudamericanas.

\section{LITERATURE CITED}

ANDRÉn, H. 1991. Predation: an overrated factor for over-dispersion of bird's nests? Animal Behaviour 41:1063-1069.

Bergin, T. M. 1992. Habitat selection by the Western Kingbird in western Nebraska: a hierarchical study. Condor 94:903-911.

Biani, N. B., J. L. Vesprini, AND D. E. Prado. 2005. Conocimiento sobre el Gran Chaco Argentino en el siglo XX, p. 1-11. In M. F. Arturi, J. L. Frangi and J. F. Goya [EDS.], Ecología y manejo de los bosques de Argentina. Editorial da la Universidad de La Plata, La Plata, Argentina.

Blendinger, P. G. 2000. Ecología trófica de aves de zonas áridas del Monte. Tesis doctoral, Universidad Nacional de Tucumán, San Miguel de Tucumán, Argentina.

BLENDINGER, P. G. 2005. Foraging behaviour of birds in an arid sanddune scrubland in Argentina. Emu 105:67-79.

Boulton, R. L., P. Cassey, C. Schipper, and M. F. Clarke. 2003. Nest site selection by Yellow-faced Honeyeaters Lichenostomus chrysops. Journal of Avian Biology 34:267-274.

Brassiolo, M. M., R. R. Renolfi, A. GräFe, And A. Fumagalli. 1993. Manejo silvopastoril en el Chaco Semiárido. Revista de Ciencias Forestales Quebracho 1:15-28.

Chalfoun, A. D., And T. E. Martin. 2007. Assessments of habitat preferences and quality depend on spatial scale and metrics of fitness. Journal of Applied Ecology 44:983-992.

Chase, M. K. 2002. Nest site selection and nest success in a Song Sparrow population: the significance of spatial variation. Condor 104:103-116. 
Clark, R. G., and D. Shutler. 1999. Avian habitat selection: pattern from process in nest-site use by ducks? Ecology 80: $272-287$.

Codesido, M., AND D. Bilenca. 2004. Variación estacional de un ensamble de aves en un bosque subtropical semiárido del Chaco argentino. Biotropica 36:544-554.

DAVIS, S. K. 2005. Nest-site selection patterns and the influence of vegetation on nest survival of mixed-grass prairie passerines. Condor 107:605-616.

Filliater, T. S., R. Reitwisch, and P. M. Nealen. 1994. Predation on Northern Cardinal nests: does choice of nest site matter? Condor 96:761-768.

GJerdrum, C., C. S. ELPHick, AND M. Rubega. 2005. Nest site selection and nesting success in saltmarsh breeding sparrows: the importance of nest habitat, timing, and study site differences. Condor 107:849-862.

Goodenough, A. E., S. L. Elliot, And A. G. Hart. 2009. Are nest sites actively chosen? Testing a common assumption for three non-resource limited birds. Acta Oecologica 35:598-602.

Hallworth, M., A. Ueland, E. Anderson, J. D. Lambert, and L. R. Hallworth. 2008. Habitat selection and site fidelity of Canada Warblers (Wilsonia canadensis) in central New Hampshire. Auk 125:880-888.

Harrison, M. L., N. A. Mahony, P. Robinson, A. Newbury, and D. J. GREEN. 2011. Nest-site selection and productivity of Vesper Sparrows breeding in grazed habitats. Journal of Field Ornithology 82:140-149.

Hartman, C. A., AND L. W. ORING. 2003. Orientation and microclimate of Horned Lark nests: the importance of shade. Condor 105:158-163.

Hingrat, Y., M. St. Jalme, T. Chalah, N. Orhant, and F. Lacroix. 2008. Environmental and social constraints on breeding site selection. Does the exploded-lek and hotspot model apply to the Houbara Bustard Chlamydotis undulata undulata? Journal of Avian Biology 39:393-404.

Hobbs, R. J., S. DeStefano, And W. L. Halvorson. 2006. Breeding biology and nest-site selection of Red-tailed Hawks in an altered desert grassland. Journal of Raptor Research 40:38-45.

JoHnson, D. H. 1979. Estimating nest success: the Mayfield method and an alternative. Auk 96:651-661.

JONES, J., AND R. J. ROBERTSON. 2001. Territory and nest-site selection of Cerulean Warblers in eastern Ontario. Auk 118:727-735.

Kristan, W. B. 2006. Sources and expectations for hierarchical structure in bird-habitat associations. Condor 108:5-12.

Kunst, C., R. Ledesma, E. Monti, J. Casillo, and J. Godoy. 2007. Gramíneas indicadoras de condición en sitios de pastizal del sudoeste de Santiago del Estero. Revista de Investigaciones Agropecuarias 36:33-61.

Liebezeit, J. R., AND T. L. George. 2002. Nest predators, nest-site selection, and nesting success of the Dusky Flycatcher in a managed ponderosa pine forest. Condor 104:507-517.

LucK, G. W. 2002. The habitat requirements of the Rufous Teecreeper (Climacteris rufa). 1. Preferential habitat use demonstrated at multiple spatial scales. Biological Conservation 105:383-394.

MARONE, L. 1991. Habitat features affecting bird spatial distribution in the Monte Desert, Argentina. Ecología Austral 1:77-86.
MARTIN, T. E. 1995. Avian life history evolution in relation to nest sites, nest predation, and food. Ecological Monographs 65:101-127.

Martin, T. E. 1998. Are microhabitat preferences of coexisting species under selection and adaptive? Ecology 79:656-670.

Martin, T. E., C. Paine, C. J. Conway, W. M. Hochachka, P. Allen, AND W. Jenkins. 1997. BBIRD field protocol. University of Montana, Missoula, MT.

MARZluff, J. M. 1988. Do Pinyon Jays alter nest placement based on prior experience? Animal Behavior 36:1-10.

MaYfield, H. F. 1975. Suggestions for calculating nest success. Wilson Bulletin 87:456-466.

Mayor, S. J., D. C. Schneider, J. A. Schaefer, and S. P. Mahoney. 2009. Habitat selection at multiple scales. Ecoscience 16:238-247.

MezQuidA, E. T. 2004. Nest site selection and nesting success of five species of passerines in a South American open Prosopis woodland. Journal of Ornithology 145:16-22.

MezQuida, E. T., AND L. Marone. 2002. Microhabitat structure and avian nest predation risk in an open Argentinean woodland: an experimental study. Acta Oecologica 23:313-320.

MezQuida, E. T., AND L. Marone. 2003. Comparison of the reproductive biology of two Poospiza warbling-finches of Argentina in wet and dry years. Ardea 91:251-262.

Misenhelter, M. D., AND J. T. RotenberRy. 2000. Choices and consequences of habitat occupancy and nest site selection in Sage Sparrows. Ecology 81:2892-2901.

Nalwanga, D., P. Lloyd, M. A. Du Plessis, And T. E. Martin. 2004. The influence of nest-site characteristics on the nesting success of the Karoo Prinia (Prinia maculosa). Ostrich 75:269-274.

Neto, J. M. 2006. Nest-site selection and predation in Savi 's Warblers Locustella luscinioides. Bird Study 53:171-176.

Nevoux, M., J. C. Barbraud, AND C. Barbraud. 2008. Breeding experience and demographic response to enviromental variability in the White Stork. Condor 110:55-62.

Peluc, S. I., T. S. Sillett, J. T. Rotenberry, and C. K. GHALAMBOR. 2008. Adaptive phenotypic plasticity in an island songbird exposed to a novel predation risk. Behavioral Ecology 19:830-835.

Ramsay, S. G., K. Otter, and L. G. Ratcliffe. 1999. Nest-site selection by female Black-capped Chickadees: settlement based on conspecific attraction? Auk 116:604-617.

Ridgely, R., AND G. Tudor. 1994. The bird of South America, volume II: the suboscine passerines. University of Texas Press, Austin, TX.

Robertson, B. A. 2009. The influence of spatio-temporal variation in food availability and nest-predation risk on clutch-size decisions. Condor 111:523-533.

SAGARIO, M. C. 2010. Limitación poblacional de las aves granívoras en la porción central del desierto del Monte. Tesis doctoral. Universidad de Buenos Aires, Buenos Aires, Argentina.

VAn Riper, C. III, M. D. Kern, AND M. K. Sogge. 1993. Changing nest placement of Hawaiian Common Amakihi during the breeding cycle. Wilson Bulletin 105:436-441.

Whittingham, M. J., S. M. Percival, And A. F. Brown. 2002. Nestsite selection by golden plover: why do shorebirds avoid nesting on slopes? Journal of Avian Biology 33:184-190.

Wiebe, K. L., And K. Martin. 1998. Costs and benefits of nest cover for ptarmigan: changes within and between years. Animal Behaviour 56:1137-1144. 